\title{
Prevalence and Characterization of Hepatitis C Virus in Hemodialysis Patients
}

\author{
Takashi Morikawa, Keisuke NaKata, Keisuke Hamasaki, Shohtaro Tsuruta, Yuji Kato, Kazuhiko NaKaO*, \\ Toshio OHTSubo** and Katsumi EguchI
}

\begin{abstract}
Object Chronic hepatitis C virus (HCV) infection is common in hemodialysis (HD) patients. In the present study, the prevalence and properties of $\mathrm{HCV}$ in HD patients were analyzed. Methods and Results Of $125 \mathrm{HD}$ patients, $34(27 \%)$ were positive for antibody to HCV, and HCV-RNA was detected in $23(68 \%)$ of the 34 patients using reverse transcription polymerase chain reaction. The HCV-RNA sequence analysis did not identify the alterations specific to HD patients with $\mathrm{HCV}$, although one patient had a variant virus containing the deletion of the core gene sequence. When serial changes in the levels of HCV-RNA were evaluated in 15 patients by a branched DNA assay, the values decreased immediately after HD procedure, but returned to the baseline values 2 days after the procedure. Conclusion These results indicate that $\mathrm{HCV}$ in $\mathrm{HD}$ patients is replication-competent, although a transient reduction in the levels of HCV-RNA occurs during HD.
\end{abstract}

(Internal Medicine 38: 626-631, 1999)

Key words: hypervariable region 1, core gene sequence, polymerase chain reaction (PCR)

\section{Introduction}

Chronic hepatitis $\mathrm{C}$ virus (HCV) infection is a common problem in patients who receive hemodialysis (HD). In fact, previous studies have demonstrated that as many as 10 to $40 \%$ of $\mathrm{HD}$ patients are chronically infected by $\mathrm{HCV}$, although $\mathrm{HCV}$ prevalence in HD patients is highly variable among different countries and even among HD units in the same area (1-3). The high prevalence of HCV in HD patients is believed to be attributed to the transfusion of HCV-contaminated blood products before the availability of reliable HCV screening. In addition, some investigators have shown that the length of time on $\mathrm{HD}$ is an independent predictor of $\mathrm{HCV}$ infection in chronic HD patients $(4,5)$. This finding suggests nosocomial transmission of $\mathrm{HCV}$ within HD units.

For editorial comment, see also p 615.

The levels of serum aminotransferases are usually normal or only slightly elevated in HD patients with $\operatorname{HCV}(1,6)$. Uremia is considered to predispose a patient to a chronic viral carrier status with little inflammatory activity in the liver. However, recent studies analyzing the liver biopsy samples of HD patients with HCV have shown that a large proportion of the patients have apparent chronic liver disease such as chronic active hepatitis and cirrhosis $(7,8)$. Moreover, changes in immune status caused by immunosuppression after renal transplantation can promote the development of clinically significant inflammatory liver disease.

In the present study, the prevalence rates of antibody to $\mathrm{HCV}$ (anti-HCV) and HCV-RNA in 125 patients who received HD for more than 1 year in our hospital were evaluated by a commercially available kit (2nd generation) and by reverse transcription polymerase chain reaction assay (RT-PCR), respectively. Furthermore, to elucidate the properties of HCV in HD patients, the effects of HD on the HCV-RNA sequence and the level of HCV-RNA were analyzed in these patients.

\section{Patients}

\section{Patients}

One hundred and twenty-five patients who received HD for 1 to 24 years (mean, 9.8) in Kouseikai Hospital, Nagasaki, Japan were studied. The sample population included 61 men and 64 women, and they were 27 to 88 years of age (mean, 55). The causes of chronic renal failure were chronic glomerulone-

From the First Department of Internal Medicine, Nagasaki University School of Medicine, Nagasaki, *Health Research Center, Nagasaki University, Nagasaki and $* *$ Kouseikai Hospital, Nagasaki

Received for publication September 24, 1998; Accepted for publication February 23, 1999

Reprint requests should be addressed to Dr. Takashi Morikawa, the First Department of Internal Medicine, Nagasaki University School of Medicine, 1-7-1 Sakamoto, Nagasaki 852-8501 
phritis ( $n=79)$, diabetic nephropathy $(n=9)$, chronic pyelonephritis $(n=9)$, polycystic kidney disease $(n=5)$, lupus nephritis $(n=2)$, amyloidosis $(n=1)$ and unknown etiology $(n=20)$. All patients received HD treatment for 4-5 hours 3 times a week. The serum levels of alanine aminotransferase (ALT) were regularly measured before each $\mathrm{HD}$ procedure at a 1 month interval. Tests for hepatitis B surface antigen (HBsAg) and antibody to $\mathrm{HCV}$ (anti-HCV, 2nd generation) were performed in all patients using commercially available enzyme-linked immunosorbent assay kits (Dainabot and Ortho Diagnostic Systems, respectively). The serum samples immediately before and after HD procedure and 2 days after the procedure were obtained from each patient with informed consent and stored at $-40^{\circ} \mathrm{C}$ for later analysis of the $\mathrm{HCV}$ genomes.

\section{Qualitative and quantitative analyses of $\mathrm{HCV}$.}

The serum samples taken immediately before HD procedure were subjected to analysis for the presence of HCV-RNA by RT-PCR using a commercially available kit (Amplicor, Roche Diagnostic Systems). In patients who were positive for HCV-RNA by RT-PCR, HCV genotypes were determined by the method described previously by Okamoto et al (9). The genomic variations in the hypervariable region 1 (HVR1) existing in the putative E2/NS-1 domain and the core region of HCV were analyzed by using the PCR-single strand conformation polymorphism (PCR-SSCP) assay and direct sequencing, respectively. In the PCR-SSCP assay, the sequence encompassing HVR1 was amplified by the nested PCR using the two sets of primers, external sense primer (nucleotide 12841304), 5'-GCATGGGACATGATGATCAACTGG-3', external antisense primer (nucleotide 1847-1867), 5' GGGGTGAAACAGTACACTGGGCC-3', internal sense primer (nucleotide 1335-1365), 5'-GAGCCTTGGAATTCC AGTTACTCCGGATCCCACAA-3', and internal antisense primer (nucleotide 1566-1592), 5'-AGAGGTGAGAA TTCGTGCCAACTGCCGTTGGTGTT-3' $(10,11)$. The PCR product ( $257 \mathrm{bp}$ in size) was diluted to $1 / 16(\mathrm{vol} / \mathrm{vol})$ with a solution containing $98 \%$ formamide and $20 \mathrm{mmol} / \mathrm{l}$ ethylenediaminetetraacetic acid, heat-denatured at $80^{\circ} \mathrm{C}$ for 5 minutes, chilled on ice, and subjected to electrophoresis in a $10 \%$ to $20 \%$ density gradient polyacrylamide gel at $300 \mathrm{~V}$ for 3 hours at $10^{\circ} \mathrm{C}$. The separated bands on the gel were visualized with silver staining. Since heterogenous mixtures of mutant genomes are separated into different bands depending on sequence-specific conformations by this assay, the degree of complexity of HVR1 quasispecies was expressed as the number of the bands detected in each patient. Direct sequencing of the core region of $\mathrm{HCV} 1 \mathrm{~b}$ was performed. Briefly, the two sets of primers based on the published sequence of HCJ4 strain were used: external sense primer (nucleotide 144-167), 5' TGGTCTGCGGAACCGGTGAGTACA-3', external antisense primer (nucleotide 927-956), 5'-GTTCGTGACATGGTA TATCCCGGACACGTT- $3^{\prime}$, internal sense primer (nucleotide 316-339), 5'-CCGGGAGGTCTCGTAGACCGTGCA-3', and internal antisense primer (nucleotide 927-956), 5'GTTCGTGACATGGTATATCCCGGACACGTT-3'. The PCR was performed for 40 cycles, in which each cycle included denaturation at $94^{\circ} \mathrm{C}$ for 1 minute, annealing at $60^{\circ} \mathrm{C}$ for 1 minute, and primer extension at $72^{\circ} \mathrm{C}$ for 1 minute. Residual dNTPs and oligonucleotide primers were removed by centrifugation filtration columns (Suprec-02; Takara, Kyoto). Nucleotide sequences were directly determined by the dideoxy chain termination method using the Taq Dye Primer Cycle Sequencing Kit (Applied Biosystems, Ink., Foster, CA) and the Applied Biosystems Model 373A DNA Sequencing System (Applied Biosystems, Ink.) (12).

The serum levels of HCV-RNA were measured by a branched DNA (bDNA) assay (Chiron Corp.). This assay involves the hybridization of synthetic oligonucleotides to the highly conserved $5^{\prime}$ noncoding region and the core gene of the HCV RNA (13). The detection limit of this assay was $0.50 \times 10^{6} \mathrm{HCV}$ genome equivalents per milliliter $(0.5 \mathrm{mEq} / \mathrm{ml})$. When patients had HCV-RNA levels of $0.5 \mathrm{mEq} / \mathrm{ml}$ (a detection limit) or more in the serum samples taken immediately before the HD procedure, the levels of HCV-RNA immediately and 2 days after HD procedure were also measured by a bDNA assay.

\section{Statistical Analysis.}

Results are expressed as mean \pm SD. Comparisons were performed with Student's t test and the chi-square test. All P values were two-tailed, and $P$ values of less than 0.05 were considered to indicate statistical significance.

\section{Results}

\section{Prevalence rates of anti-HCV and HCV-RNA in HD patients}

Of $125 \mathrm{HD}$ patients, $34(27 \%)$ were positive for anti-HCV, and $23(68 \%)$ of these 34 patients were also positive for HCVRNA by RT-PCR. HCV-RNA could not be detected in any patients who were negative for anti-HCV (Table 1). The mean age and sex ratios were almost similar in anti-HCV-positive and -negative patients. However, the duration of HD in antiHCV-positive patients was significantly longer than that in antiHCV-negative patients $(\mathrm{p}<0.01)$, while the difference was not significant in HCV-RNA-positive and -negative patients with anti-HCV. Thirty-one (91\%) of 34 anti-HCV-positive patients had histories of blood transfusions, as did $55(60 \%)$ of antiHCV-negative patients $(\mathrm{p}<0.01)$. HCV screening in blood donors started in 1989 in Japan. Considering evaluation of the time of blood transfusion in each case, 30 of 31 patients who had histories of blood transfusions and were positive for antiHCV received blood transfusions before 1989. The levels of serum ALT were monitored monthly for more than 1 year in all patients. The values were consistently within the normal limit (less than $35 \mathrm{IU} / l$ ) in a large proportion of the patients irrespective of the positivities of anti-HCV or HCV-RNA. One (3\%) of 34 anti-HCV-positive patients and 5 (5\%) of 91 anti$\mathrm{HCV}$-negative patients were positive for HBsAg. In the analysis of the viral genotypes in $23 \mathrm{HCV}$-RNA-positive patients, $19(83 \%)$ and $3(13 \%)$ had HCV1b and HCV2a, respectively. 


\section{Variations of $\mathrm{HCV}$ in $\mathrm{HD}$ patients}

To investigate the variations of $\mathrm{HCV}$ in HD patients, the

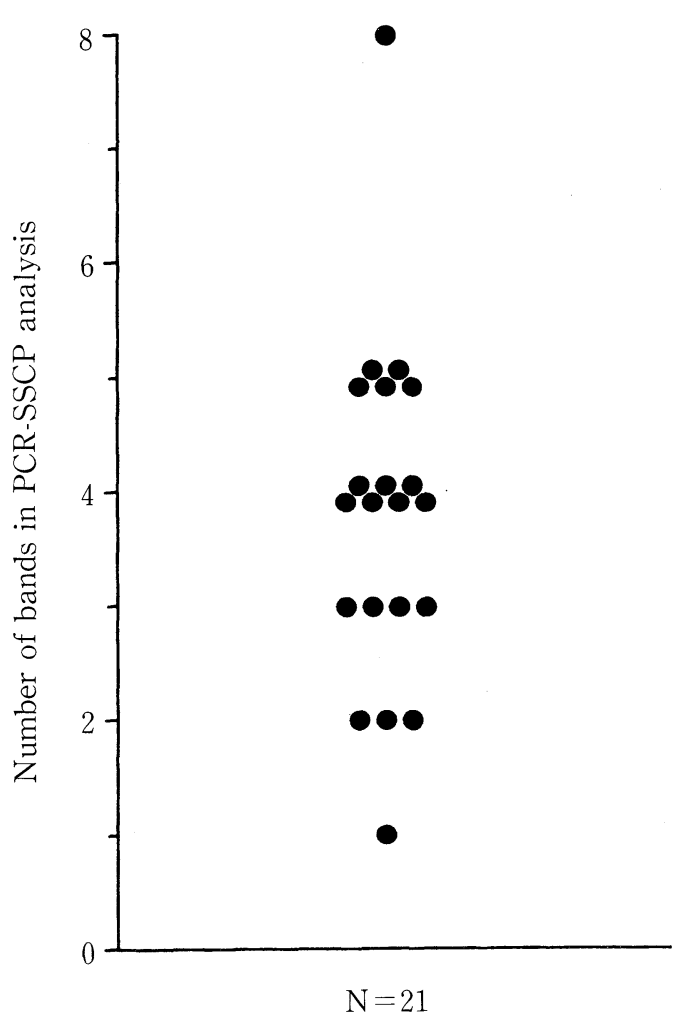
sequences of HVR 1 and the core region of HCV were analyzed. In 21 of 23 patients who were positive for HCV-RNA, serum samples were available for analysis of the HVR1 quasispecies by the PCR-SSCP assay. As shown in Fig. 1, the number of bands separated on the gel corresponding to the degree of the HVR1 quasispecies complexity was widely varied, ranging from 1 to 8 (mean, 3.8) in each patient.

The sequence of the HCV core region could be analyzed in 16 of 19 patients with HCV1b by direct sequencing. In comparison with the amino acid sequence of HCJ4 strain used as a reference sequence, the amino acid substitutions were found mainly in the median portion of the core protein in HD patients (Fig. 2). However, the alterations relevant to HD patients with HCV could not be identified, although one patient had a variant virus which contained a deletion of the core gene sequence between nucleotide 114 and nucleotide 326, resulting in a deletion of the amino acid sequence between the 39th codon

Figure 1. Variations of hypervariable region 1 (HVR1) of HCV were analyzed in 21 of 23 hemodialysis patients who were positive for HCV-RNA. The degree of complexity of HVR1 quasispecies was assessed by the number of bands on PCR-SSCP analysis as decribed in Materials and Methods.

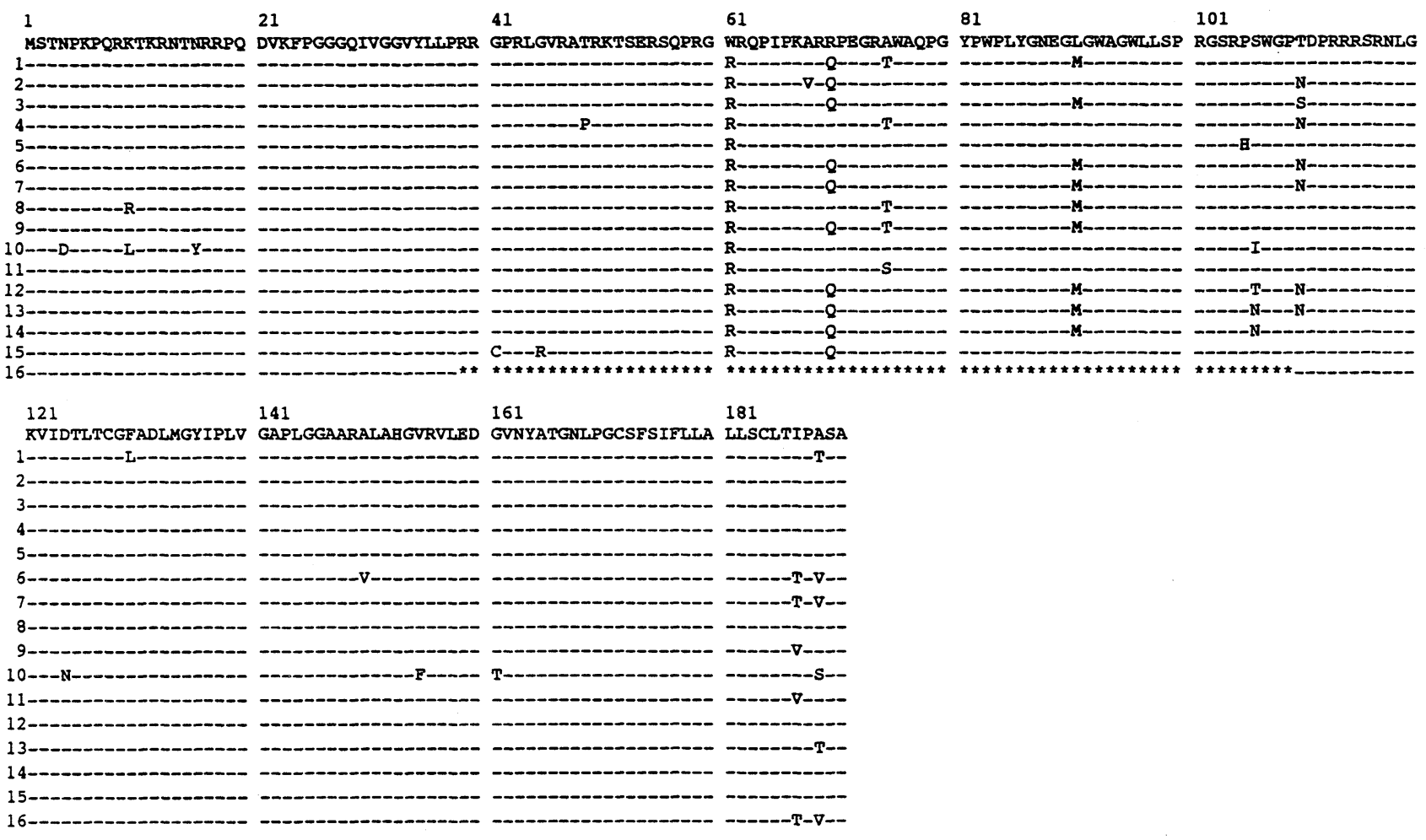

Figure 2. Analysis of $\mathrm{HCV}$ core region sequences in 16 hemodialysis patients with $\mathrm{HCV} 1 \mathrm{~b}$. The amino acid sequence of the HCJ4 strain is shown as a reference sequence in the upper column. The asterisks indicate the deleted sequence of the HCV core region in one patient (case 16). 


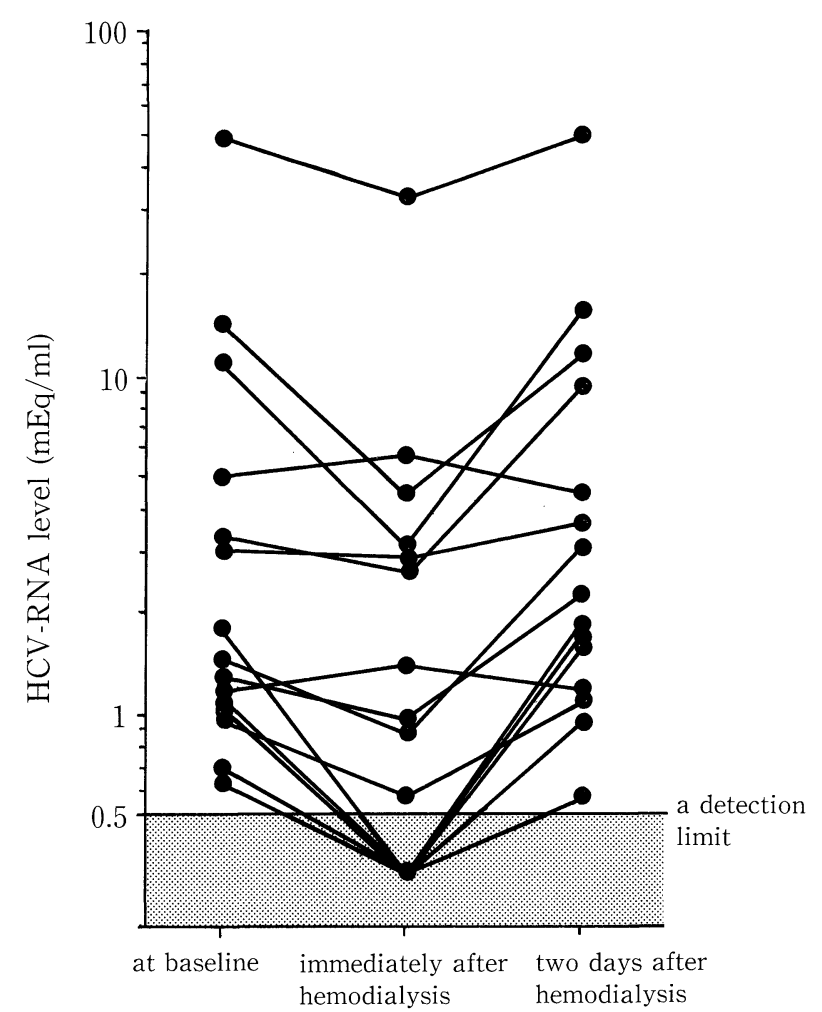

Figure 3. Time course analysis of HCV-RNA levels in 15 hemodialysis patients. The levels of HCV-RNA were measured by a branched DNA (bDNA) assay. To ensure that association was not dependent on the computation level, the analysis was done with bDNA assay-negative samples set at $0.5 \mathrm{mEq} / \mathrm{ml}$. The HCV-RNA level immediately after HD procedure (mean $[ \pm \mathrm{SD}], 3.9 \pm 8.2 \mathrm{mEq} / \mathrm{ml}$ ) was significantly lower than those at baseline and at 2 days after HD procedure (mean $[ \pm \mathrm{SD}], 6.5 \pm 12.7 \mathrm{mEq} / \mathrm{ml}$ and $7.8 \pm 13.7 \mathrm{mEq} /$ $\mathrm{ml}, \mathrm{p}<0.05$, respectively).

and the 110th codon in the core region.

\section{Quantitative analysis of HCV in HD patients}

The serum levels of HCV-RNA were measured by a bDNA assay in 23 patients who were positive for HCV-RNA by RTPCR. Of 23 patients, $15(65 \%)$ had detectable levels of HCVRNA in sera taken immediately before the HD procedure, with the values ranging from $0.6 \mathrm{mEq} / \mathrm{ml}$ to $50 \mathrm{mEq} / \mathrm{ml}$. When serial changes in the levels of HCV-RNA were determined in the 15 patients, the values were found to be significantly reduced immediately after the HD procedure in a large proportion of patients with $\mathrm{HCV}$, compared with the baseline values $(\mathrm{p}<0.01$, Fig. 3). However, the reduced levels were restored to the baseline values 2 days after the HD procedure in these patients.

\section{Discussion}

Chronic HCV infection affects approximately $30 \%$ of patients on maintenance HD (1-3). The majority of HD patients with HCV have only a minimal derangement in the ALT level $(1,6)$. However, recent histological analysis of the liver tissue indicates that $\mathrm{HD}$ patients with $\mathrm{HCV}$ often have chronic active hepatitis or cirrhosis $(7,8)$. The serum level of vitamin $B_{6}$ which is indispensable for the measurement of ALT activity is reduced in HD patients (14). This results in relatively low levels of serum ALT in HD patients despite the presence of progressive liver disease in some of these patients. In addition, the patients with normal liver enzyme levels during HD can still develop progressive liver disease after renal transplantation $(5,15)$. Expression of interleukin- $1 \beta$ and tumor necrosis factor- $\alpha$ (TNF- $\alpha$ ) as well as expression of their inhibitors such as interleukin- 10 and soluble receptors of TNF- $\alpha$ have been shown to be elevated in HD patients $(16,17)$. Such an imbalance between cytokines and their inhibitors may play a pivotal role in the multifaceted process of immune dysfunction in HD patients. Therefore, characterization of HCV in HD patients is of importance for the understanding and management of the virusassociated inflammatory liver disease in these patients.

In the present study, the prevalence rate of anti-HCV in 125 HD patients was $27 \%$. The rate was higher in patients who received $\mathrm{HD}$ for a relatively longer period, suggesting the risk of nosocomial transmission of HCV within the HD unit as reported previously $(18,19)$. Taken together, HCV infection acquired by blood transfusions without HCV screening appears to be the main cause of the viral transmission in HD patients, because approximately $88 \%$ of anti-HCV-positive patients had a history of blood transfusions before HCV screening in the present study. Of $34 \mathrm{HD}$ patients with anti-HCV, 23 (68\%) were also positive for HCV-RNA by RT-PCR. This is consistent with the results described previously, where serum HCV-RNA was detected in approximately $80 \%$ of HD patients who were positive for anti-HCV (1-3). Of $23 \mathrm{HCV}$-RNA-positive patients, $19(83 \%)$ had the viral genotype $1 \mathrm{~b}$, which was relatively similar to recent results in Japan, where HCV $1 \mathrm{~b}$ was found in approximately $70 \%$ of patients with HCV (9). Since intermittent hepatitis $\mathrm{C}$ viremia in HD patients was reported previously (20), a single negative result does not reflect spontaneous remission. Accordingly, the regular follow-up studies including serial testing for the presence of HCV-RNA by RT-PCR will be necessary in HD patients who are positive for anti-HCV but negative for HCV-RNA as well as patients who are positive for both.

In the HCV-RNA sequence analysis, the complexity of HVR1 quasispecies was evaluated by the PCR-SSCP assay. The degree of the HVR1 quasispecies complexity assessed by the number of bands in HD patients with HCV was nearly similar to that reported previously in patients with chronic hepatitis $\mathrm{C}$ who did not receive $\mathrm{HD}(10,21)$. Antibodies directed to HVR1 of HCV have recently been shown to neutralize the corresponding $\mathrm{HCV}$ isolate in vitro (22). Moreover, recent studies have shown that the sequences of HVR1 of HCV found in earlier time points of infection are rapidly mutated during chronic infection because of an immune escape of newly arising viral variants of HVR1 (23). These results suggest that the appearance of viral variants of HVR1 is associated with viral persistence in patients who do and do not receive HD. The HCV 
core gene sequences were also analyzed in this study. The amino acid substitutions were found in each patient. However, no particular substitutions relevant to HD patients with $\mathrm{HCV}$ were elucidated, although it is noteworthy that one patient had a variant virus containing the deletion of the core gene sequence. The deletion mutant and the full length HCV would be coinfected in the same hepatocyte and would synthsize viral particles as seen in chronic HBV infection (24). Since the HCV core region has several epitopes which play a crucial role in the immune response to $\operatorname{HCV}(25,26)$, alterations or a deletion in this region in HD patients can operate on escape from immune pressure, leading to persistence of viral infection. Furthermore, the reduced immune defense resulting from an imbalance between cytokines and their inhibitors $(16,17)$ might also be involved in viral persistence in HD patients.

The time course analysis of the levels of viremia in HD patients with $\mathrm{HCV}$ represented a reduction of the levels of HCVRNA immediately after HD procedure. However, the reduced levels were restored to the baseline values 2 days after the procedure. Similar results were described by Okuda et al, who reported that the levels of HCV-RNA in blood significantly decreased after each HD procedure (27). In addition, several groups have shown that, in contrast to patients with $\mathrm{HCV}$ who do not receive HD, fluctuation of the level of viremia is frequently observed in HD patients with $\operatorname{HCV}(20,28)$. Hayashi et al have recently demonstrated the adsorption of HCV particles onto the dialyzer membrane (29), although the mechanism of the adsorption in which many factors including the size or the charge of viral particles or the presence of immunoglobulins associated with viral particles may be affected is not fully understood. This finding is likely to account for the transient reduction or fluctuation of the levels of HCV-RNA in the clinical course of HD patients with HCV.

In summary, alterations in the HCV sequence seem to be similar in patients who do and do not receive HD. Although the transient reduction of the levels of HCV-RNA during HD procedure occurs in a large proportion of patients, $\mathrm{HCV}$ is replicable in these patients. Worsening of the virus-associated liver inflammation after renal transplantation has often been recognized in $\operatorname{HD}$ patients with $\operatorname{HCV}(5,15)$. Previous studies have shown that the frequency of HD patients with HCV who result in sustained response to interferon is similar to or relatively higher than that of patients who do not receive $\operatorname{HD}(30,31)$. Taken together, the low pretreatment level of HCV-RNA is an important predictor of response to interferon in patients who do and do not receive HD (30-32). Thus, interferon treatment prior to renal transplantation is a possible strategy for the eradication of $\mathrm{HCV}$ in HD patients, particularly in those who have relatively low levels of viremia.

Acknowledgements: The authors thank M. Matsuo and T. Yoshikawa for skillful technical assistance.

\section{References}

1) Chan TM, Lok AS, Cheng IK, Chan RT. Prevalence of hepatitis C virus infection in hemodialysis patients: A longitudinal study comparing the results of RNA and anti-body assays. Hepatology 17: 5-8, 1993.

2) DuBois DB, Gretch D, Rosa C, et al. Quantitation of hepatitis C viral RNA in sera of hemodialysis patients: Gender-related differences in viral load. Am J Kidney Dis 24: 795-801, 1994.

3) Kuhns M, de Medina M, McNamara A, et al. Detection of hepatitis $C$ virus RNA in hemodialysis patients. J Am Soc Nephrol 4: 1491-1497, 1994.

4) Mondelli MU, Cristina G, Piazza V, Cerino A, Villa G, Salvadeo A. High prevalence of antibodies to hepatitis $\mathrm{C}$ virus in hemodialysis units using a second-generation assay. Nephron 61: 350-351, 1992.

5) Pol S, Romeo R, Zins B, et al. Hepatitis $\mathrm{C}$ virus RNA in anti-HCV positive hemodialyzed patients: Significance and therapeutic implications. Kidney Int 44: 1097-1100, 1993.

6) Bouchardeau F, Chauveau P, Le Marrec N, Girault A, Zins B, Courouce AM. Detection of hepatitis $\mathrm{C}$ virus by polymerase chain reaction in haemodialysed patients in relationship to anti-HCV status. Res Virol 144: 233-242, 1993.

7) Caramelo C, Ortiz A, Aguilera B, et al. Liver disease patterns in hemodialysis patients with antibodies to hepatitis $\mathrm{C}$ virus. Am J Kidney Dis 22: 822-828, 1993.

8) al Meshari K, al Ahdal M, Alfurayh O, Ali A, De Vol E, Kessie G. New insights into hepatitis $C$ virus infection in hemodialyis patients: The implications. Am J Kidney Dis 25: 572-578, 1995.

9) Okamoto H, Sugiyama Y, Okada S, et al. Typing hepatitis C virus by polymerase chain reaction with type-specific primers: application to clinical surveys and tracing infectious sources. J Gen Viro 73: 673-679, 1992.

10) Shindo M, Arai K, Sokawa Y, Okuno T. The virological and histological states of anti-hepatitis $\mathrm{C}$ virus-positive subjects with normal liver biochemical values. Hepatology 22: 418-425, 1995.

11) Orita M, Iwahana $H$, Kanazawa $H$, Hayashi $K$, Sekiya $T$. Detection of polymorphisms of human DNA by gel electrophoresis as single-strand conformation polymorphisms. Proc Natl Acad Sci USA 86: 2766-2770, 1989.

12) Kurosaki M, Enomoto N, Marumo F, Sato C. Variations in the core region of hepatitis $\mathrm{C}$ virus genomes in patients with chronic hepatitis. Arch Virol 140: 1087-1094, 1995.

13) Lau JY, Davis GL, Kniffen J, et al. Significance of serum hepatitis $C$ virus RNA levels in chronic hepatitis C. Lancet 341: 1501-1504, 1993.

14) Kleiner MJ, Tate SS, Sullivan JF, Chami J. Vitamin $B_{6}$ deficiency in maintenance dialysis patients: metabolic effects of repletion. Am J Clin Nutr 33: $1612-1619,1980$

15) Morales JM, Munoz MA, Castellano G, et al. Impact of hepatitis C in long-functioning renal transplants: a clinicopathological follow-up. Transplant Proc 25: 1450-1453, 1993.

16) Descamps-Latscha B, Herbelin A, Nguyen AT, et al. Balance between IL$1 \beta$, TNF- $\alpha$, and their specific inhibitors in chronic renal failure and maintenance dialysis. Relationships with activation markers of T cells, B cells, and monocytes. J Immunol 154: 882-892, 1995.

17) Schindler R, Linnenweber $S$, Schulze $M$, et al. Gene expression of interleukin-1 $\beta$ during hemodialysis. Kidney Int 43: 712-721, 1993.

18) Sampietro $M$, Badalamenti $S$, Salvadori $S$, et al. High prevalence of a rare hepatitis $C$ virus in patients treated in the same hemodialysis unit: Evidence for nosocomial transmission of HCV. Kidney Int 47: 911-917, 1995.

19) de Lamballerie $X$, Olmer M, Bouchouareb D, Zandotti C, De Micco P. Nosocomial transmission of hepatitis $\mathrm{C}$ virus in Haemodialysis patients. $\mathrm{J}$ Med Virol 49: 296-302, 1996.

20) Fabrizi F, Martin P, Dixit V, et al. Acquisition of hepatitis $C$ virus in hemodialysis patients: A prospective study by branched DNA signal amplification assay. Am J Kidney Dis 31: 647-654, 1998.

21) Naito M, Hayashi N, Moribe $T$, et al. Hepatitis $C$ viral quasispecies in hepatitis $C$ virus carriers with normal liver enzyme and patients with type C chronic liver disease. Hepatology 22: 407-412, 1995.

22) Kato N, Sekiya H, Ootsuyama $Y$, et al. Humoral immune response to hypervariable region 1 of the putative envelope glycoprotein (gp70) of hepatitis C virus. J Virol 67: 3923-3930, 1993.

23) Weiner AJ, Geysen HM, Christopherson C, et al. Evidence for immune 


\section{$\mathrm{HCV}$ in Hemodialysis Patients}

selection of hepatitis $\mathrm{C}$ virus (HCV) putative envelope glycoprotein variants: potential role in chronic HCV infection. Proc Natl Acad Sci USA 89: 3468-3472, 1992.

24) Yuan TT, Lin MH, Qiu SM, Shih C. Functional characterization of naturally occurring variants of human hepatitis $\mathrm{B}$ virus containing the core internal deletion mutation. J Virol 72: 2168-2176, 1998.

25) Kita H, Moriyama T, Kaneko T, et al. HLA B44-restricted cytotoxic T lymphocytes recognizing an epitope on hepatitis $\mathrm{C}$ virus nucleocapsid protein. Hepatology 18: 1039-1044, 1993.

26) Koziel MJ, Dudley D, Afdhal N, et al. Hepatitis C virus (HCV)-specific cytotoxic $\mathrm{T}$ lymphocytes recognize epitopes in the core and envelope proteins of HCV. J Virol 67: 7522-7532, 1993.

27) Okuda K, Hayashi H, Yokozeki K, Irie Y. Destruction of hepatitis C virus particles by haemodialysis. Lancet 347: 909-910, 1996.
28) Umlauft F, Gruenewald $K$, Weiss G, et al. Patterns of hepatitis $C$ viremia in patients receiving hemodialysis. Am J Gastroenterol 92: 73-78, 1997.

29) Hayashi $\mathrm{H}$, Okuda $\mathrm{K}$, Yokosuka $\mathrm{O}$, et al. Adsorption of hepatitis $\mathrm{C}$ virus particles onto the dialyzer membrane. Artif Organs 21: 1056-1059, 1997.

30) Chan TM, Wu PC, Lau JY, Lok ASF, Lai CL, Cheng IK. Interferon treatment for hepatitis $\mathrm{C}$ virus infection in patients on haemodialysis. Nephrol Dial Transplant 12: 1414-1419, 1997.

31) Izopet J, Rostaing $L$, Moussion F, et al. High rate of hepatitis $C$ virus clearance in hemodialysis patients after interferon- $\alpha$ Therapy. J Infect Dis 176: 1614-1617, 1997.

32) Hagiwara $\mathrm{H}$, Hayashi $\mathrm{N}$, Mita $\mathrm{E}$, et al. Quantitative analysis of hepatitis $\mathrm{C}$ virus RNA in serum during interferon alfa therapy. Gastroenterology 104: $877-883,1993$. 